\title{
Microstructure and mechanical properties of two- step Cu-alloyed ADI treated by different second step austempering temperatures and times
}

\author{
Peng-yue Yi, *Er-jun Guo, Li-ping Wang, Yi-cheng Feng, Chang-liang Wang \\ School of Material Science and Engineering, Harbin University of Science and Technology, Harbin, China
}

\begin{abstract}
Austempering ductile iron (ADI) is an attractive material due to its excellent comprehensive mechanical properties. However, the deficit in elongation and toughness always threatens its security application. Two-step austempering process is an effective way to improve elongation and toughness simultaneously. In the present work, the influence of the amount, morphology and distribution of ferrite and austenite on mechanical properties of ADI under different second-step austempering parameters has been analyzed. Results show that the amount of austenite and its carbon content decrease with increasing of second-step temperature. Carbide begins to precipitate as second-step austempering temperature reaches $380{ }^{\circ} \mathrm{C}$. These factors together influence the mechanical properties of two-step Cu-alloyed ADI. Impact energy and fracture toughness are strongly affected by second-step austempering temperature, and are dramatically decreased with increase of second-step austempering temperature. Elongation remains constant when the second-step temperature is below $360{ }^{\circ} \mathrm{C}$, and then it is rapidly decreased with further increase of second-step temperature. Strength is slightly influenced by second-step temperature. Ferrite morphology is not influenced by second-step austempering duration, while blocky retained austenite size is slightly decreased with the increasing of second-step austempering time. The amount of retained austenite is decreased while the carbon content of retained austenite is increased with the extending of second-step austempering time. The substructure of austenite is transformed from dislocation to twin when second-step austempering time exceeds $60 \mathrm{~min}$. Strength and elongation are improved slightly with extending of second-step time. Impact energy and fracture toughness initially decrease with the extending of second-step time, and then remain constant when the time is longer than $60 \mathrm{~min}$. This is a result of austenite content decreasing and carbon content of austenite increasing. The second-step austempering time mainly influences austenite content and its carbon content, which is a result of carbon diffusion behavior variation.
\end{abstract}

Key words: two-step austempering process; Cu-alloyed ADI; microstructure; mechanical properties; fracture toughness
CLC numbers: TG143.5
Document code: A
Article ID: 1672-6421(2019)05-342-10

\begin{abstract}
$\mathrm{A}$ ustempered ductile iron (ADI) is widely used in transmission components, such as engine crankshafts and gears, due to its excellent comprehensive mechanical properties ${ }^{[1-5]}$. Good elongation and toughness is essential to ensure the safety application of these components ${ }^{[6]}$. Therefore, it is important for ADI to improve elongation and toughness without compromising strength ${ }^{[7-9]}$. Research and development of ADI possessing both high strength and high elongation and toughness is important issue, which is also the main
\end{abstract}

\section{*Er-jun Guo}

Male, born in 1963, Ph.D., Professor. His research interests mainly focus on nodular ductile cast irons and cast steels.

E-mail: guoerjunees@163.com

Received: 2019-05-20; Accepted: 2019-07-08 purpose of this paper.

The two-step austempering process is an effective method to improve strength and toughness of ADI simultaneously ${ }^{[16-20]}$. Putatunda and Yan ${ }^{[17]}$ attributed the strengthening mechanism of this novel process to microstructure refinement and retained austenite and its carbon content increasing. However, the effects of each step austempering temperature and holding time on microstructure evolution and mechanical properties, are still not clear. The role of each step needs to be discussed in depth to reveal the strengthening mechanism of twostep austempering process of ADI.

Moreover, the material used in studies of two-step austempering process is always high-cost CuNiMoalloyed ADI. Cu-alloyed ADI can effectively reduce the cost, and previous study has shown that $\mathrm{Cu}$ can improve 
the plasticity and toughness of ADI without significant strength decrease ${ }^{[21]}$. Therefore, in this study, $\mathrm{Cu}$-alloyed ductile iron is selected as the research object, and the effects of secondstep temperature and time on microstructure and mechanical properties of ADI were studied. The strengthening mechanism of two-step austempering process is also discussed.

\section{Experimental procedure}

\subsection{Casting blocks preparation and heat treatment}

The chemical composition of the spheroidal graphite iron used in this study was $3.6 \% \mathrm{C}, 2.6 \% \mathrm{Si}, 0.4 \% \mathrm{Mn}, 1.4 \% \mathrm{Cu}$, and Fe the balance. The iron was melted in a GWJ- 0.25 medium frequency induction furnace, and heated to over $1,500{ }^{\circ} \mathrm{C}$. Then, the sandwich nodularizing treatment process (RE3Mg8 nodulizer and $75 \mathrm{SiFe}$ inoculation) was conducted. The melted iron was static cooled down to about $1,300{ }^{\circ} \mathrm{C}$ and finally poured into Y-shaped block molds.

Two different kinds of Y-shaped blocks were cast, as shown in Fig. 1. The $25 \mathrm{~mm}$ thick Y-shaped block, Fig. 1 (a), was used for tensile and impact testing. The $75 \mathrm{~mm}$ thick Y-shaped block was roughly cut into three pieces along the length direction (90 $\mathrm{mm})$, as shown in Fig. 1 (b), and then machined to $25 \mathrm{~mm}$ thick specimens used for plane strain fracture toughness tests. The locations of specimens were also shown in Fig. 1. All the Y-shaped sand molds were prepared by silicon-sand and phenolic resin binder. The sand molds were buried into a gray cast iron flask to prevent expansion cracking caused by spheroidal graphite precipitation.
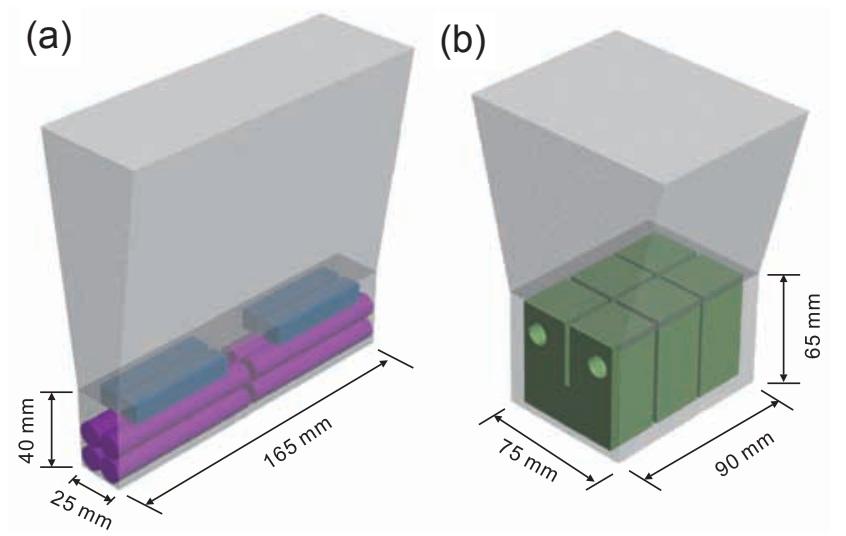

Fig. 1: Y-shaped block and sampling location: (a) block used for tensile and impact test; (b) block used for fracture toughness test

The heat treatment process route is shown in Fig. 2. All the specimens were austenitized at $900{ }^{\circ} \mathrm{C}$ for $90 \mathrm{~min}$ in the furnace without gas protection, and then rapidly quenched into a salt bath at $280{ }^{\circ} \mathrm{C}$ for $15 \mathrm{~min}$ (first-step austempering). The second-step austempering was carried out at $320-400{ }^{\circ} \mathrm{C}$ for $30-90 \mathrm{~min}$ (Table 1). Finally, these samples were air cooled at room temperature. Among these specimens, Specimens \#1-5 were used to investigate the influence of second step austempering temperature on twostep ADI, Specimens \#1 and \#6-8 were used to investigate the influence of the second-step austempering time on two-step ADI.

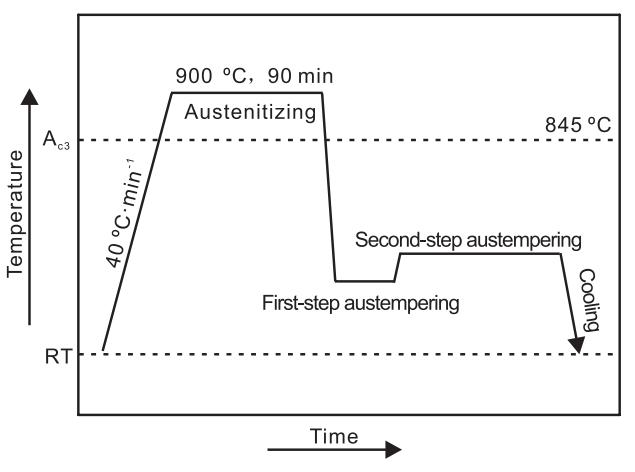

Fig. 2: Route of two-step austempering heat-treat process

Table 1: Parameters of second-step austempering process

\begin{tabular}{ccc|} 
Sample No. & $\begin{array}{c}\text { Second-step } \\
\text { temperature }\left({ }^{\circ} \mathrm{C}\right)\end{array}$ & $\begin{array}{c}\text { Second-step holding } \\
\text { time }(\mathrm{min})\end{array}$ \\
$\# 1$ & 320 & 45 \\
$\# 2$ & 340 & 45 \\
$\# 3$ & 360 & 45 \\
$\# 4$ & 380 & 45 \\
$\# 5$ & 400 & 45 \\
$\# 6$ & 320 & 30 \\
$\# 7$ & 320 & 60 \\
$\# 8$ & 320 & 90 \\
\end{tabular}

\subsection{Microstructure characterization}

Optical microscopy (OM, OLYMPUS-GX71), scanning electron microscopy (SEM, FEI-Quanta200, $20 \mathrm{kV}$ ) and transmission electron microscopy (TEM, JEM-2100, 200 $\mathrm{kV}$ ) methods were used for microstructure observation and analysis. The metallographic specimens used for OM and SEM were ground by water-proof metallographic sand paper from \#200 to \#2000 grit, and then were polished and etched. TEM specimens were prepared by wire cutting, and then were mechanically thinned from $500 \mu \mathrm{m}$ to $40 \mu \mathrm{m}$. Ion-milling (Gatan-691, $20 \mu \mathrm{A}, 3^{\circ}-6^{\circ}$ ) was conducted to prepare the final TEM specimens.

X-ray diffraction (XRD) was used to calculate the austenite quantity and its carbon content. The X-ray diffractometer (D/max-2600/PC, Rigaka, Japan) was employed with $\mathrm{Cu}$ $\mathrm{K} \alpha$ radiation at $40 \mathrm{kV}$ and $150 \mathrm{~mA}$, with a scanning rate of $3{ }^{\circ} \mathrm{C} \cdot \mathrm{min}^{-1}$ in the range of $30-100^{\circ}$. The size of the specimen was $10 \mathrm{~mm} \times 10 \mathrm{~mm} \times 1.5 \mathrm{~mm}$. Volume fraction of the retained austenite was estimated using the following equation:

$$
\frac{I_{\gamma\{\mathrm{hk} l\} \mathrm{i}}}{I_{\alpha\{\mathrm{hk} 1\} \mathrm{j}}}=\frac{R_{\gamma\{\mathrm{hk} 1\} \mathrm{i}} X_{\gamma}}{R_{\alpha\{\mathrm{hk} 1\} \mathrm{j}} X_{\alpha}}
$$

where $I_{\gamma\{\mathrm{hk} l\} \mathrm{i}}$ and $I_{\alpha\{\mathrm{hk}\}\} \mathrm{j}}$ are the integrated intensities of a given $\{\mathrm{hkl}\}$ plane from the austenite and ferrite, respectively, $X_{\gamma}$ and $X_{\alpha}$ are the volume fractions of austenite and ferrite, $\frac{R_{\gamma\{\mathrm{hk} l\} \mathrm{i}}}{R_{\alpha\{\mathrm{hk} l\} \mathrm{j}}}$ is the ratio of intensity factors corresponding to the 
crystal plane of $\{h k l\} i$ from austenite and $\{h k l\} j$ from ferrite

The $\{200\},\{220\}$ and $\{311\}$ planes of austenite and $\{200\}$ and $\{211\}$ planes of ferrite were used to analyze the volume fraction of austenite. The volume fraction of austenite was calculated by each $\frac{I_{\left.\gamma_{\{} \mathrm{hkl}\right\} \mathrm{i}}}{I_{\alpha\{\mathrm{hkl}\} \mathrm{j}}}$, and the result was the average of six values. The carbon content of austenite was determined by the following equation:

$$
a_{\gamma}=0.358+0.0044 C_{\gamma}
$$

where $a_{\gamma}$ is the lattice parameter of austenite (nm) and $C_{\gamma}$ is the carbon content of austenite (wt.\%).

\subsection{Mechanical properties test}

Tensile testing was conducted at room temperature on an electronic universal testing machine (CCS-44300) according to Standards GB/T 24733-2009 and GB/T 228-2002, the gauge length is $35 \mathrm{~mm}$ and tensile rate was $4 \mathrm{~mm} \cdot \mathrm{min}^{-1}$. The final value was the average of three tests.

Impact energy specimens $(10 \mathrm{~mm} \times 10 \mathrm{~mm} \times 55 \mathrm{~mm})$ were tested in a pendulum impact testing machine (NCS-NI300) at room temperature according to Standard GB/T 229-2007. The final value was the average of the highest five test values of six test specimens.

Plane fracture toughness testing was conducted in a servohydraulic test system (MTS-810) according to Standard GB/ $\mathrm{T}$ 4161-2007. The size of the compact tension specimen (CT specimen) was $25 \mathrm{~mm} \times 60 \mathrm{~mm} \times 62 \mathrm{~mm}$, and $50 \mathrm{~mm}$ in effective width. All the specimens were polished before testing, and a $2 \mathrm{~mm}$ long fatigue crack was pre-cracked by $\Delta K$ level of $10 \mathrm{MPa} \cdot \mathrm{m}^{1 / 2}$. The final value was the average of three tests.

\section{Results and discussion}

\subsection{Microstructure}

\section{(1) Second step austempering temperature}

The optical microstructures of two-step Cu-alloyed ADI treated by different second-step temperatures and holding for $45 \mathrm{~min}$ are shown in Fig. 3. The ferrite is gradually coarsened as the second-step temperature increases. When the second-step temperature exceeds $360{ }^{\circ} \mathrm{C}$, the ferrite becomes darker. The blocky austenites' size increases significantly as the secondstep temperature increases from $320^{\circ} \mathrm{C}$ to $360{ }^{\circ} \mathrm{C}$. When the second-step austempering temperature reaches $400{ }^{\circ} \mathrm{C}$, the blocky austenites change to fine precipitated phase.

Figure 4 shows SEM images of two-step Cu-alloyed ADI. When the second-step temperature is below $360{ }^{\circ} \mathrm{C}$, two different kinds of ferrite morphologies are distinguished. The ferrite marked by yellow dash line consists of fine ferrite laths, which are paralleled. The distance between ferrite laths is small. There is no blocky austenite distributed between ferrite laths. It is customarily named as acicular ferrite and is formed during the first-step austempering process. The ferrite marked by red arrows is another morphological ferrite. The thickness of ferrite laths and the distance between ferrite laths are much greater than acicular ferrites. Blocky retained austenites are distributed between coarse ferrites. They are named as bunched ferrites to distinguish these ferrites possessed different morphologies. Bunched ferrites are formed during the second-step austempering process. As the second-step temperature increases, the difference of morphology becomes more clear. When the second-step temperature is over $360{ }^{\circ} \mathrm{C}$, the ferritic morphology becomes ambiguous. Blocky austenites disappear when the second-step temperature reaches $400{ }^{\circ} \mathrm{C}$. Boundaries of ferrites are not able to distinguish.
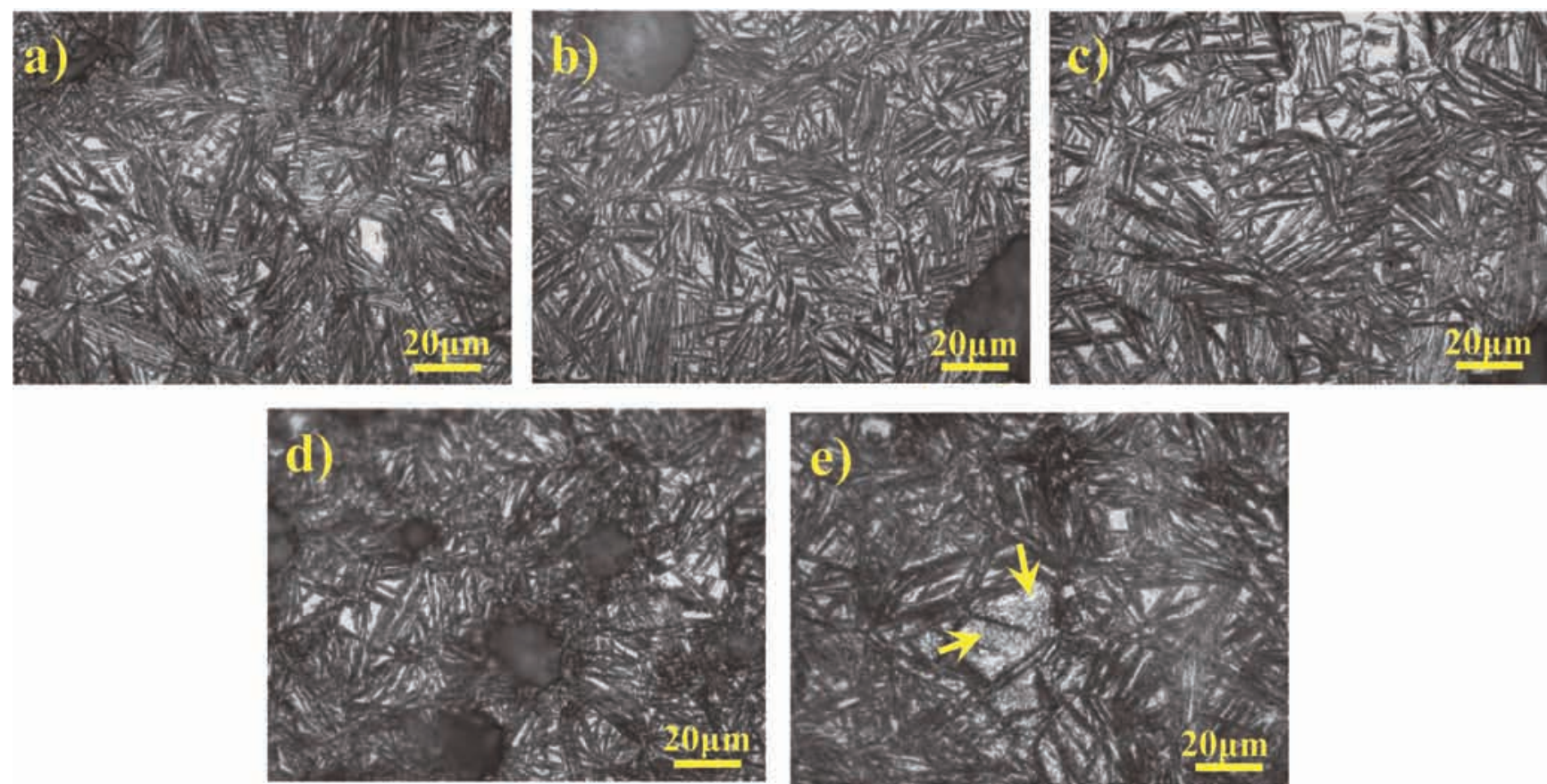

Fig. 3: Optical microstructures of nodular graphite iron treated by different second-step austempering temperatures and holding for $45 \mathrm{~min}$ : (a) $320^{\circ} \mathrm{C}$; (b) $340^{\circ} \mathrm{C}$; (c) $360^{\circ} \mathrm{C}$; (d) $380^{\circ} \mathrm{C}$; (e) $400^{\circ} \mathrm{C}$ 

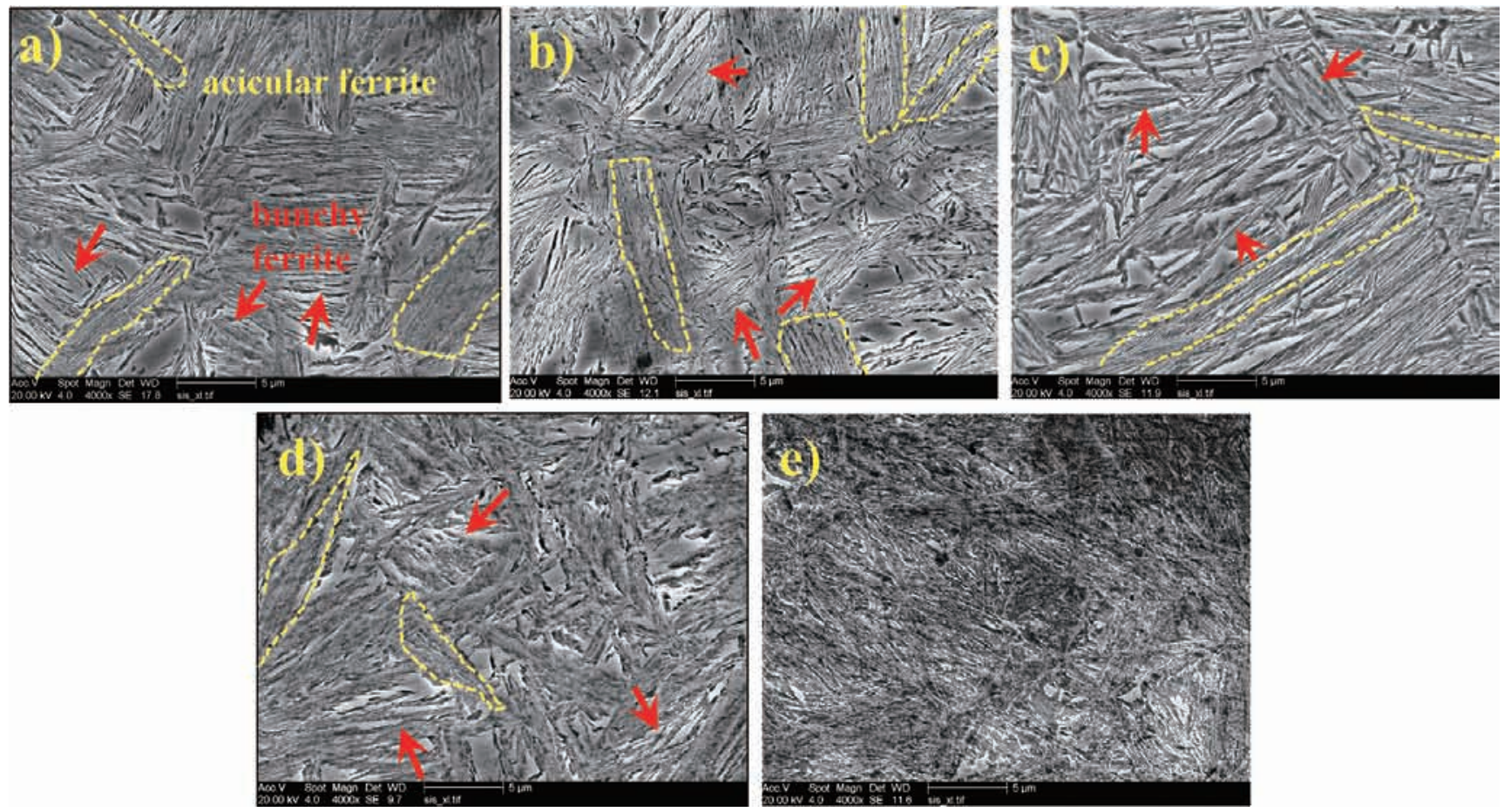

Fig. 4: SEM micrograph of nodular graphite iron treated by different second-step austempering temperatures and holding for $45 \mathrm{~min}$ : (a) $320^{\circ} \mathrm{C}$; (b) $340^{\circ} \mathrm{C}$; (c) $360^{\circ} \mathrm{C}$; (d) $380{ }^{\circ} \mathrm{C}$; (e) $400{ }^{\circ} \mathrm{C}$

TEM images are shown in Fig. 5. As the second-step austempering temperature increases, two different kinds of ferrites can be distinguished [Figs. 5(a) and (c)]. The finer ferrite with paralleled arrangement is transformed during the first-step austempering, and the thicker ferrite is transformed during the second-step austempering. Thickness of finer ferrite lath is constant with an increase in the second-step temperature. When the second-step temperature increases from $320{ }^{\circ} \mathrm{C}$ to $400{ }^{\circ} \mathrm{C}$, bunched ferrite lath is significantly thickened from $100 \mathrm{~nm}$ to $190 \mathrm{~nm}$. High density dislocations are distributed in ferrite lath as shown in higher magnification TEM images [Fig. 5(b), (d) and (f)]. The film-like austenite is thickened from 100 $\mathrm{nm}$ to $200 \mathrm{~nm}$ as the second-step temperature increases from 320 to $360{ }^{\circ} \mathrm{C}$. When the second-step temperature reaches 400 ${ }^{\circ} \mathrm{C}$, a large number of carbides are precipitated and film-like austenite disappears. The carbide is $\mathrm{Fe}_{3} \mathrm{C}$, identified by SAED pattern [Fig. 5(e)]. The carbide precipitation locations are parallel layered which are similar to the arrangement of ferrite laths and film-like austenites. This indicates that the austenite decomposition is the reason for carbide precipitation. Therefore, the thickness of film-like austenite which is formed at $400{ }^{\circ} \mathrm{C}$ before austenite decomposition is about $400 \mathrm{~nm}$. This indicates that the austenite is further coarsened with increase of the second-step temperature from $360{ }^{\circ} \mathrm{C}$ to $400{ }^{\circ} \mathrm{C}$. Meanwhile, the substructures of film-like austenites are dislocations and stacking faults, the dislocation density of the film-like austenite is much lower than ferrite laths and is changed little with the increase of second-step temperature [Fig. 5(b) and (d)]. Stacking fault might inherit from parent austenite due to collineation of stacking fault between paralleled austenite films ${ }^{[30]}$. The observation by TEM indicates that the different morphological ferrites are essentially the same in composition and structure, but have different thicknesses and distributions.

Volume fraction of austenite and its carbon content are shown in Fig. 6. Retained austenite content decreases from $30.87 \%$ to $3.2 \%$ as the second-step temperature increases. Meanwhile, the carbon content of austenite is continuously reduced from $1.87 \%$ to $1.66 \%$ with the increasing of secondstep temperature from $320{ }^{\circ} \mathrm{C}$ to $400{ }^{\circ} \mathrm{C}$. This trend is contrary to the common rule of ADI treated by a single step austempering process.

Generally, austenite content increases with the increase of austempering temperature in a traditional single step austempering process ${ }^{[22-24]}$. Putatunda selected CuNiMo-alloyed ductile iron as the research object and adopted a lower firststep temperature and a shorter first-step austempering time $\left(240{ }^{\circ} \mathrm{C} \times 5 \mathrm{~min}\right)$. A similar result to single step austempering process was obtained ${ }^{[20]}$. However, in this study, austenite content is instead decreased with increasing of second-step austempering temperature, which is because the first-step austempering temperature is higher and first-step austempering time is longer. At the start of the second-step austempering, large amounts of acicular ferrites had already formed, and the original austenite grains were simultaneously separated into fine block. According to the basic principle of bainite phase transformation ${ }^{[25,26]}$, bunched ferrite is unable to grow through the existing acicular ferrite. Therefore, the bunched ferrite is limited in the separate austenite grains. Meanwhile, existing acicular ferrite could promote nucleation of bunched ferrite. These factors together promote the refinement of bunched ferrite. As the second-step austempering temperature increases, bunched ferrite laths are thickened and shortened. 
a)
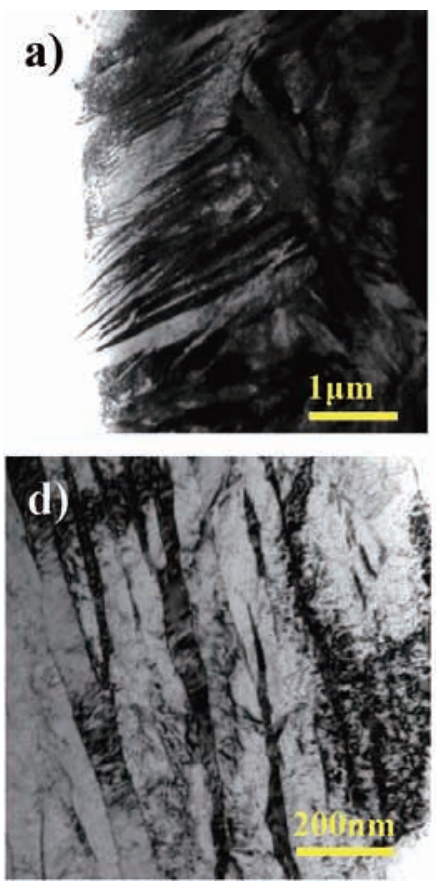
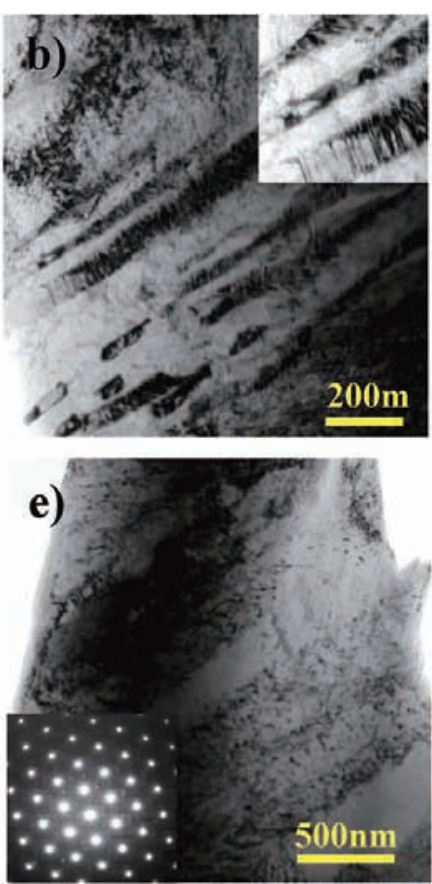
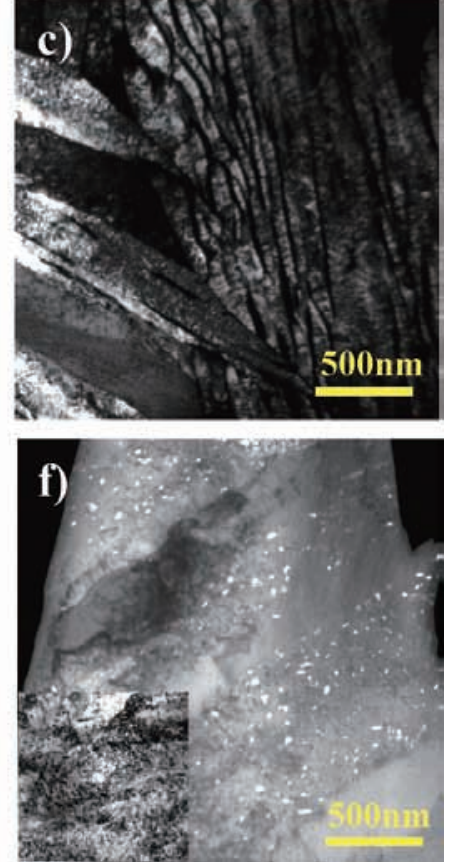

Fig. 5: TEM micrograph of nodular graphite iron treated by different second-step austempering temperatures and holding for $45 \mathrm{~min}$ : (a and b) $320^{\circ} \mathrm{C}$; (c and d) $360^{\circ} \mathrm{C}$; (e and f) $400^{\circ} \mathrm{C}$
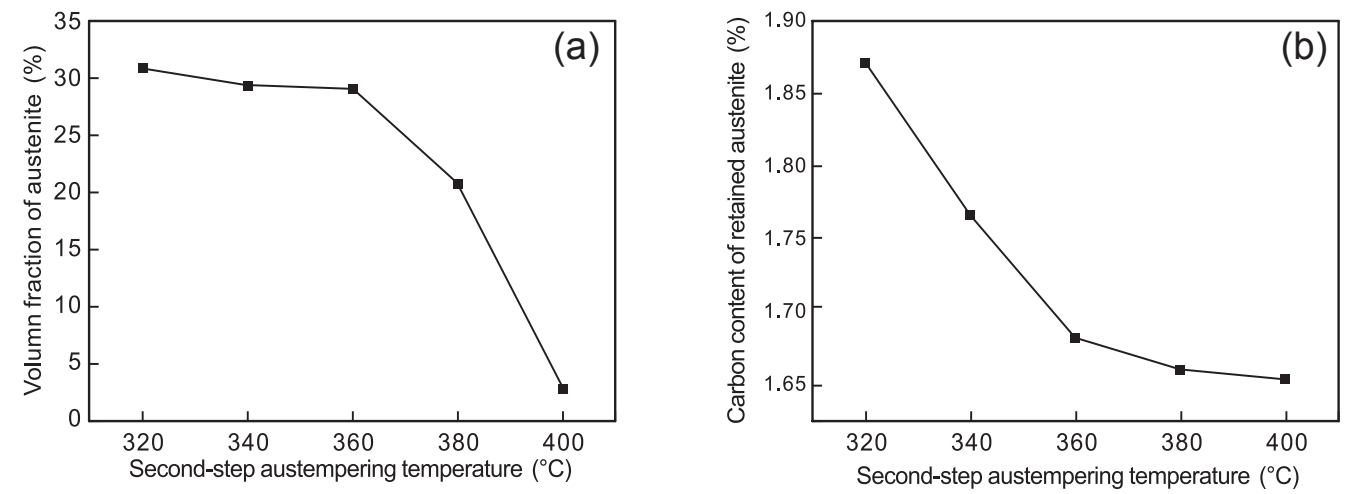

Fig. 6: X-ray diffraction result of ADI treated by different second-step austempering temperatures and holding for 45 min: (a) austenite content ; (b) austenitic carbon content

Therefore, the diffusion distance of carbon atoms from ferrite laths to austenite increases with the increase of the second-step temperature, which makes carbon more difficult to diffuse into austenite, and the stability of retained austenite is decreased. Although the diffusion rate increases with second-step temperature, the carbide formation trend is also strengthened. This is the reason for retained austenite decomposition when the second -step temperature is over $360{ }^{\circ} \mathrm{C}$. On the other hand, bainitic transformation rate increases with increase of the second-step temperature. More austenites transform to ferrites when the holding time is fixed. Therefore, austenite content and its carbon content are decreased with the increasing of the second-step austempering temperature.

\section{(2) Second-step austempering time}

The optical microstructures of the two-step Cu-alloyed ADI with different second-step times are shown in Fig. 7. When the second-step time is $30 \mathrm{~min}$, a large amount of blocky austenite is retained in the matrix and the content of bunched ferrite is low. With the extending of second-step austempering time, the size of blocky austenite decreases, and the bunched ferrite content increases.

SEM images of samples with different second-step austempering times are shown in Fig. 8. Retained austenites are divided into blocks by fine acicular ferrites. When the holding time is $30 \mathrm{~min}$, short and coarse bunched ferrites are distributed in blocky austenites as marked by red arrows. Bunched ferrites are so short that they can not grow throughout the whole blocky austenites. With the extending of secondstep austempering time, short and coarse bunchy ferrites disappear. Bunched ferrites grow throughout the whole blocky austenites, which divide the blocky austenites into finer pieces. With further extending of second-step time, the size of blocky austenites is further reduced.

TEM images of samples with different second-step austempering times are shown in Fig. 9. In extending of the second-step time, the morphologies of ferrites and austenites are almost unchanged. Thickness of ferrites is kept constant 

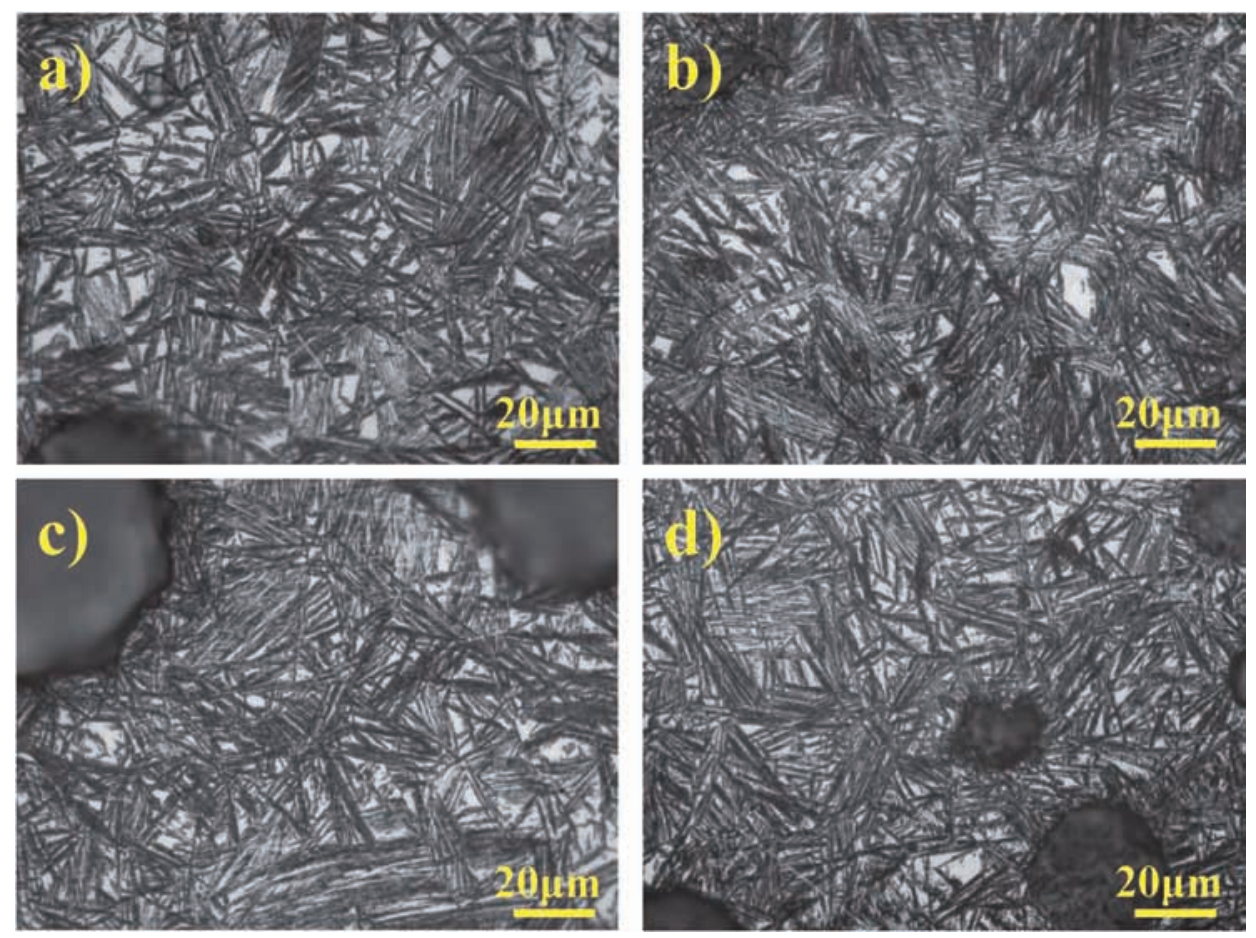

Fig. 7: Optical microstructures of nodular graphite iron austempering at $320^{\circ} \mathrm{C}$ for different times: (a) $30 \mathrm{~min}$; (b) $45 \mathrm{~min}$; (c) $60 \mathrm{~min}$; (d) $90 \mathrm{~min}$
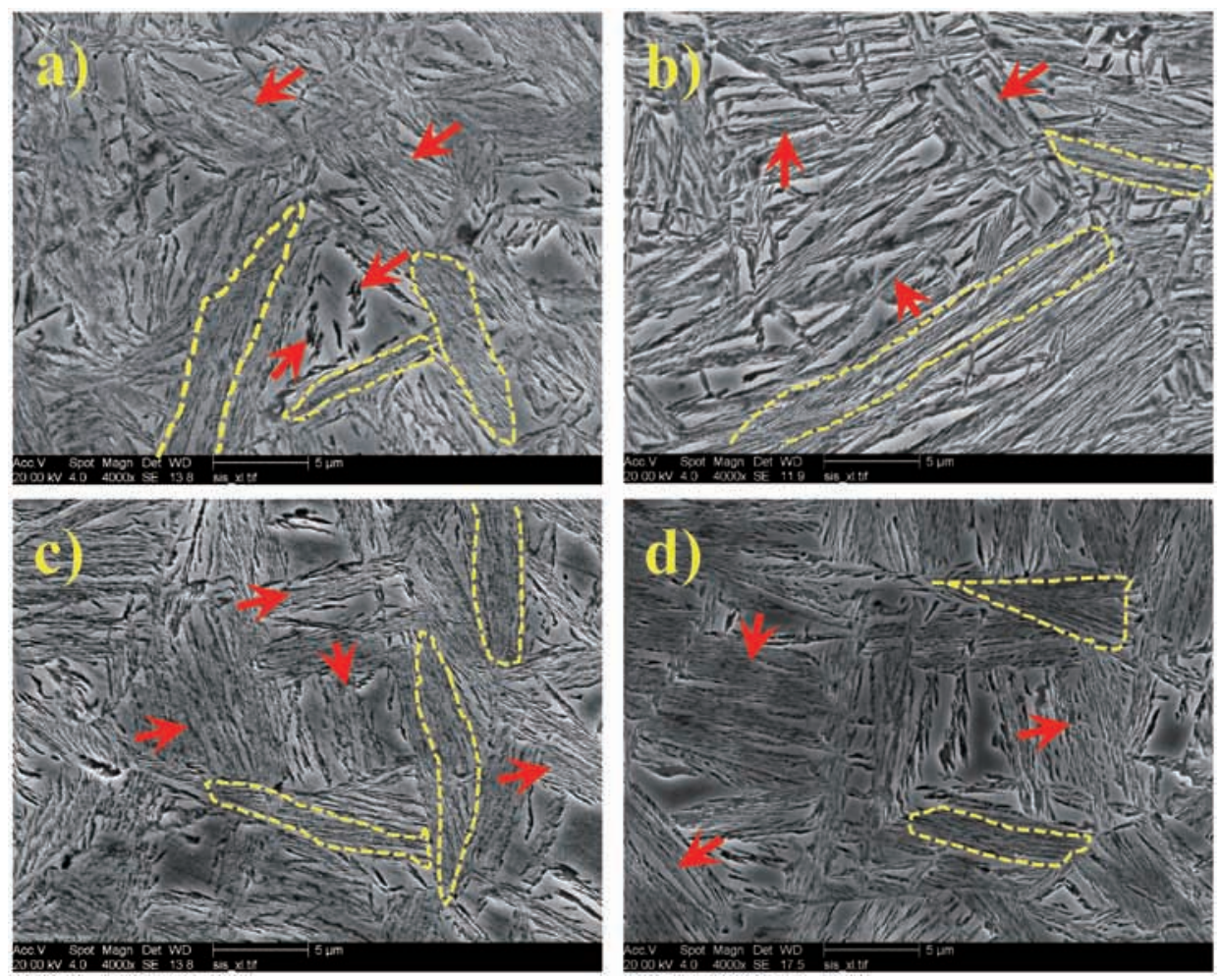

Fig. 8: SEM micrographs of nodular graphite iron austempering at $320^{\circ} \mathrm{C}$ for different second-step austempering times: (a) $30 \mathrm{~min}$; (b) $45 \mathrm{~min}$; (c) $60 \mathrm{~min}$; (d) $90 \mathrm{~min}$

at about $110 \mathrm{~nm}$, thickness of film-like austenites is kept constant at about 100-150 nm [Fig. 9(a), (c) and (e)]. High density dislocations are distributed in ferrite laths, but changed little with the extending of second-step time. However, the substructure of film-like austenites is significantly changed [Fig. 9 (b), (d) and (f)], the dislocations and stacking faults are transformed into twins with time extending. This is because the volume expansion caused by ferrite formation increases the internal stress. Hence, the austenites are deformed, and the deformation mechanism is twinning. Meanwhile, the original stacking faults in austenites provide nucleation locations of twinning, which can further refine the austenite.

Volume fraction of retained austenite and its carbon content are shown in Fig. 10. Retained austenite content is reduced 

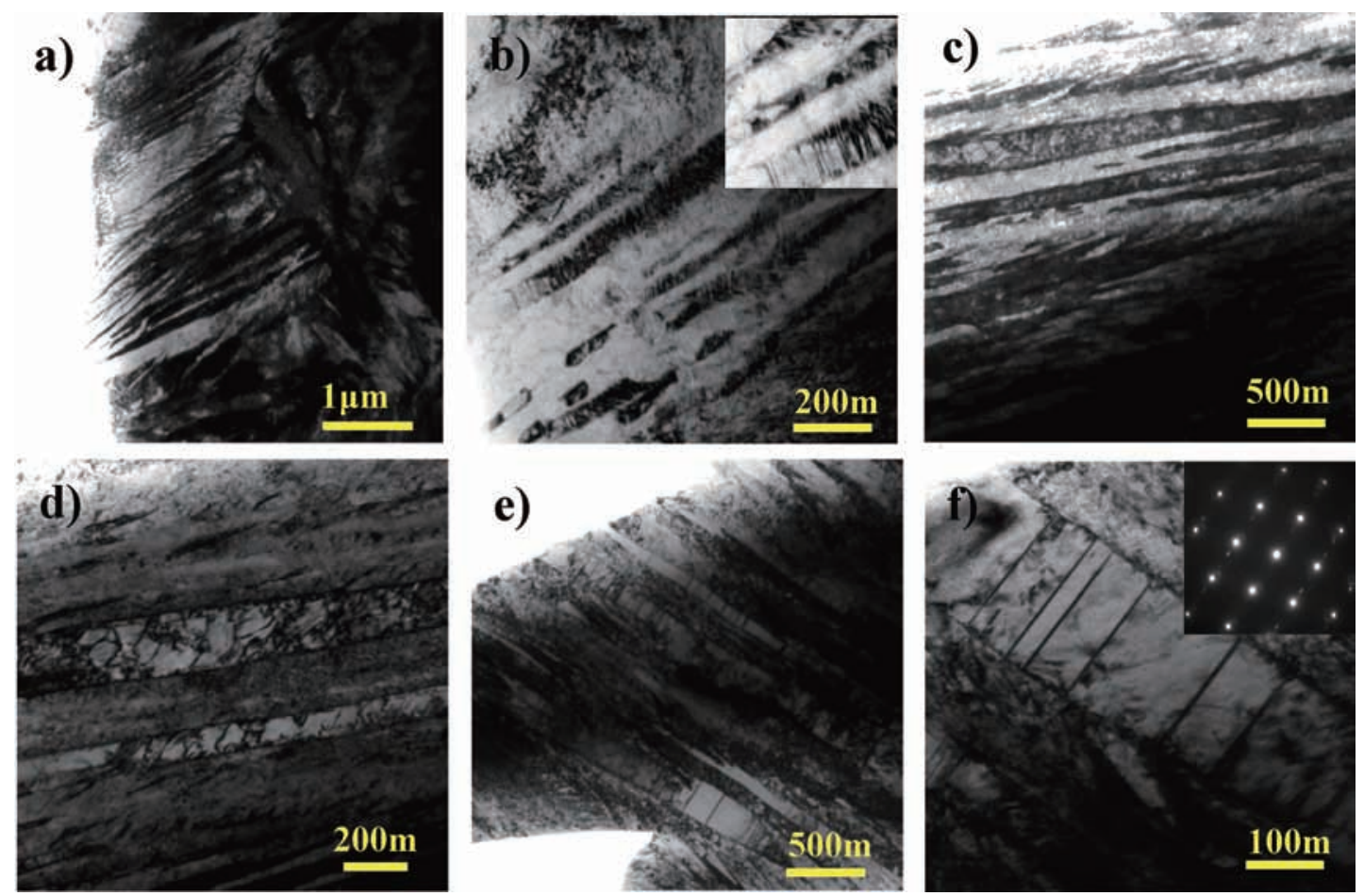

Fig. 9: TEM micrographs of nodular graphite iron austempering at $320^{\circ} \mathrm{C}$ for different second-step times: (a) $45 \mathrm{~min}$; (b) $60 \mathrm{~min}$; (c) $90 \mathrm{~min}$
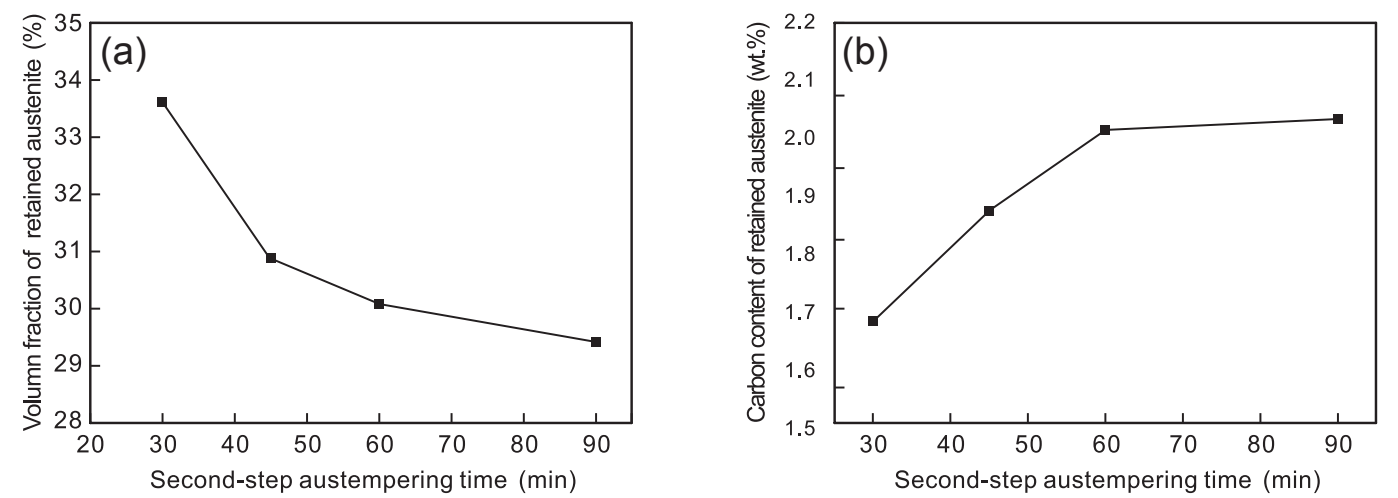

Fig. 10: X-ray diffraction result of ADI treated by different second-step austempering times: (a) austenite content ; (b) austenitic carbon content

from $33.61 \%$ to $29.42 \%$ with the second-step austempering time increasing from $30 \mathrm{~min}$ to $90 \mathrm{~min}$. Carbon content of retained austenite keeps increasing with the extending of second-step austempering time. However, as the secondstep austempering time is over $60 \mathrm{~min}$, the carbon content of retained austenite reaches saturation. With further extending of second-step austempering time, carbon content of retained austenite is almost unchanged.

There is no significant change in bunched ferrite morphology with extending of the second-step austempering time. The second-step austempering time mainly affects austenite content and its carbon content. Some austenites transform to bunched ferrites during the second-step austempering. Therefore, the austenite content is decreased with extending of the secondstep austempering time. Blocky retained austenites are thus refined. When the second-step austempering time exceedes 30 min, most of the bunched ferrites grow across the whole blocky austenites, and more carbon atoms diffuse into austenites. As the second-step austempering time extended, the carbon distribution becomes more uniform, and then the carbon content of retained austenite increases obviously. When the holding time is over 60 min, carbon content in retained austenite is saturated. Therefore, the carbon content of retained austenite remains constant with further extending of the second-step austempering time.

\subsection{Mechanical properties}

(1) Second-step austempering temperature

Mechanical properties of two-step Cu-alloyed ADI with different second-step austempering temperatures are shown in Fig. 11 and Table 2. Ultimate tensile strength and yield strength decrease firstly and then increase with the second-step austempering temperature increasing from 320 to $380{ }^{\circ} \mathrm{C}$. When the secondstep austempering temperature increases to $400{ }^{\circ} \mathrm{C}$, the ultimate tensile strength and yield strength decrease to 1,290 MPa and 

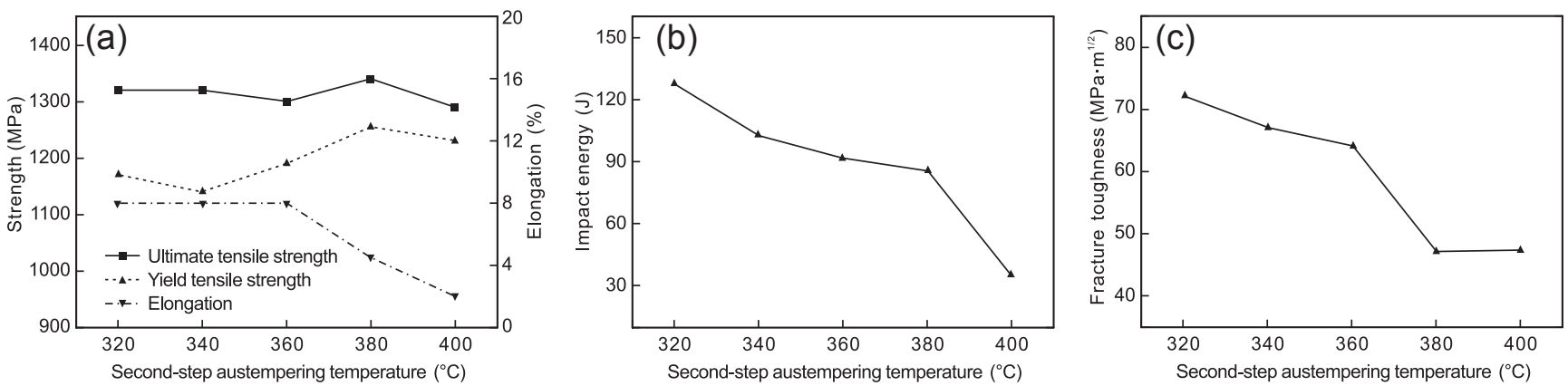

Fig. 11: Influence of second-step austempering temperature on mechanical properties of two-step Cu-alloyed ADI after firststep austempering at $280^{\circ} \mathrm{C}$ for $15 \mathrm{~min}$ : (a) tensile strength; (b) impact energy; (c) fracture toughness

Table 2: Mechanical properties of two-step Cu-alloyed ADI treated by different second-step austempering temperature

$\begin{array}{cccccc}\begin{array}{c}\text { Second step } \\ \text { temperature }\left({ }^{\circ} \mathrm{C}\right)\end{array} & \begin{array}{c}\text { Ultimate tensile } \\ \text { strength }(\mathrm{MPa})\end{array} & \begin{array}{c}\text { Yield strength } \\ (\mathrm{MPa})\end{array} & \begin{array}{c}\text { Elongation } \\ (\%)\end{array} & \begin{array}{c}\text { Impact energy } \\ (\mathrm{J})\end{array} & \begin{array}{c}\text { Fracture toughness } \\ \left(\mathrm{MPa} \cdot \mathrm{m}^{1 / 2}\right)\end{array} \\ 320 & 1320 & 1170 & 8 & 127.8 & 72.28 \\ 340 & 1320 & 1140 & 8 & 102.8 & 67.11 \\ 360 & 1300 & 1190 & 8 & 91.6 & 64.09 \\ 380 & 1340 & 1255 & 4.5 & 85.9 & 47.38 \\ 400 & 1290 & 1230 & 2 & 35.3 & 47.13\end{array}$

1,230 $\mathrm{MPa}$, respectively. Elongation remains constant at $8 \%$ as the second-step temperature increases from 320 to $360{ }^{\circ} \mathrm{C}$, but when the second-step austempering temperature exceeds $360{ }^{\circ} \mathrm{C}$, the elongation decreases dramatically. Impact energy continuously reduces from 127.8 to $35.3 \mathrm{~J}$ as the secondstep austempering temperature increases. Fracture toughness decreases from $72.28 \mathrm{MPa} \cdot \mathrm{m}^{1 / 2}$ to $47.38 \mathrm{MPa} \cdot \mathrm{m}^{1 / 2}$ as the second step austempering temperature increases from $320{ }^{\circ} \mathrm{C}$ to 400 ${ }^{\circ} \mathrm{C}$. This indicates that elongation and toughness are deteriorated as the second-step temperature increases. Especially, when the second-step austempering temperature exceeds $360{ }^{\circ} \mathrm{C}$, the elongation and toughness are reduced significantly.

The strength of the two-step Cu-alloyed ADI is approximately equaled to the strength of the matrix which is the weighted average of austenite and ferrite. When the second-step austempering temperature is $320{ }^{\circ} \mathrm{C}$, austenitic content reaches $30.87 \%$. Although Sample \#1 has higher austenite content at this second-step austempering temperature, strength is not reduced significantly. This is because the carbon content of austenite is high, resulting in higher strain hardening capacity of austenite, and therefore, increases the strength ${ }^{[29]}$. Meanwhile, refinement of bunched ferrite also increases the strength of two-step Cu-alloyed ADI. As the second-step austempering temperature increases, coarsening of bunched ferrite and decrease of austenitic carbon content are the reasons for strength decreasing. When the secondstep temperature is over $360{ }^{\circ} \mathrm{C}$, carbide formation produces precipitation strengthening. Therefore, the strength is increased when the second-step temperature is $380{ }^{\circ} \mathrm{C}$. However, when the second-step temperature reaches $400{ }^{\circ} \mathrm{C}$, granulate carbides are precipitated along the grain and original phase boundary [Fig. $5(\mathrm{e})$ and (f)], and the strength of Sample \#5 is decreased.
When the second-step austempering temperature is below $360{ }^{\circ} \mathrm{C}$, the austenite content variation is small. Hence, elongation keeps constant at $8.0 \%$. When the second-step temperature exceeds $360{ }^{\circ} \mathrm{C}$, the austenite content and its carbon content rapidly decrease, which is the reason for elongation decreasing. Meanwhile, carbide precipitation also weakens the deformation capability. Therefore, when the second-step austempering temperature exceeds $360{ }^{\circ} \mathrm{C}$, the elongation is dramatically decreased.

Impact energy continues reducing with the increasing secondstep austempering temperature. One reason for impact energy reducing is the austenite content decreasing, and the ferrite bunch coarsening is another reason. When the second-step austempering temperature is over $360{ }^{\circ} \mathrm{C}$, carbide precipitation is also a reason for impact energy decrease.

Fracture toughness is an important parameter to characterize the resistance of crack propagation, and can reflect strength and plasticity comprehensively. Crack propagation needs to overcome plastic deformation work and surface energy during plane strain fracture ${ }^{[6]}$. Surface energy has little relationship with microstructure of the two-step $\mathrm{Cu}$-alloyed ADI, while plastic deformation work is just on the contrary. Plastic deformation work is increased with enhancing of yield strength and elongation. Elongation is improved with increase of retained austenite content. Moreover, retained austenite might produce strain hardening, and then improve the strength of ADI. Carbon content of austenite is closely related to strain hardening behavior of austenite. Therefore, these factors are able to influence the fracture toughness of the ADI. As the second-step temperature increases, yield strength is changed little. However, the amount of retained austenite and carbon 
content of austenite decrease significantly with the increasing second-step temperature, which deteriorate fracture toughness. When the second-step temperature reaches $380{ }^{\circ} \mathrm{C}$, carbide precipitation further deteriorates the fracture toughness.

\section{(2) Second-step austempering time}

Mechanical properties of two-step $\mathrm{Cu}$-alloyed ADI with different second-step austempering times are shown in Fig. 12 and Table 3. In this group of specimens, the second-step temperature is fixed at $320{ }^{\circ} \mathrm{C}$ to investigate the influence of second-step time on mechanical properties of ADI. Ultimate strength, yield strength and elongation are increased with the extending of second-step austempering time. When the secondstep holding time increases to $90 \mathrm{~min}$, the ultimate tensile strength, yield strength and elongation reach the maximums of 1,350 MPa, 1,290 MPa and 9.2\%, respectively. Impact energy is reduced continuously from $132 \mathrm{~J}$ to $124 \mathrm{~J}$ with the extending of second-step austempering time. Fracture toughness increases slightly from $71.91 \mathrm{MPa} \cdot \mathrm{m}^{1 / 2}$ to $72.28 \mathrm{MPa} \cdot \mathrm{m}^{1 / 2}$ as the second-step austempering time increases from $30 \mathrm{~min}$ to
$45 \mathrm{~min}$. With further extending of second-step austempering time, fracture toughness is dramatically decreased to 67.99 $\mathrm{MPa} \cdot \mathrm{m}^{1 / 2}$. Fracture toughness increases slightly and reaches $68.03 \mathrm{MPa} \cdot \mathrm{m}^{1 / 2}$ with further extending of the second-step time. Generally, the mechanical properties have no obvious change with the increasing of second-step austempering time.

Strength is little influenced by second-step austempering time due to inapparent microstructure change. Fracture toughness is mainly influenced by retained austenite content and its carbon content. When the second-step austempering time is less than $45 \mathrm{~min}$, fracture toughness is much higher than the specimens treated by a longer time. This is because the carbon content of austenite is lower under a short holding time. Carbon content reaches saturation when the holding time exceeds $60 \mathrm{~min}$, which ensures the stability of retained austenite. Energy consumption on martensite transformation is decreased. Therefore, fracture toughness of samples treated by a longer second-step time (Samples 7\# and 8\#) is lower than those treated by a shorter second-step time.
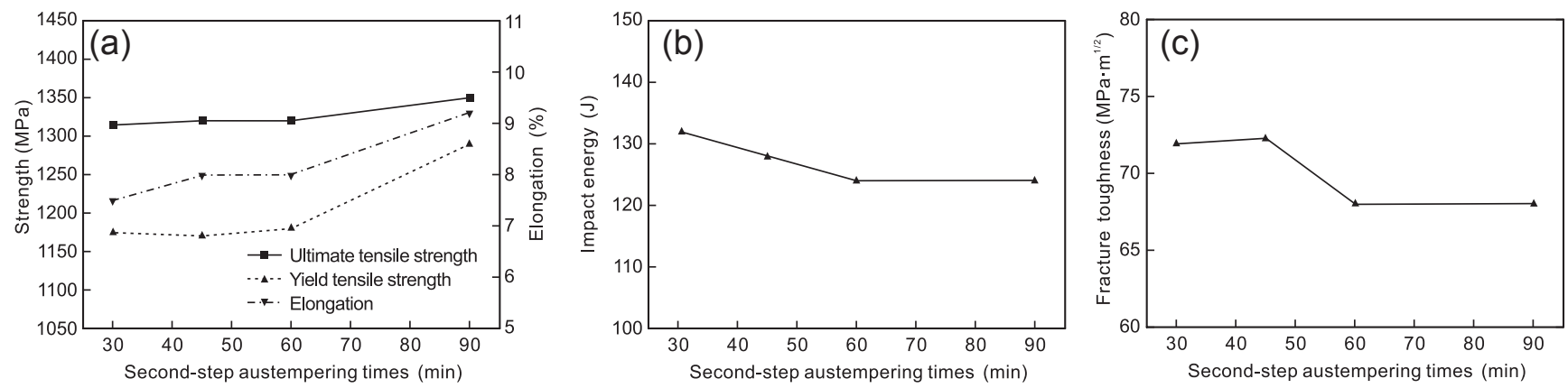

Fig. 12: Influence of second-step austempering time (second-step austempering temperature was $320^{\circ} \mathrm{C}$ ) on mechanical properties of two-step Cu-alloyed ADI: (a) tensile strength; (b) impact energy; (c) fracture toughness

Table 3: Mechanical properties of two-step Cu-alloyed ADI treated at $320^{\circ} \mathrm{C}$ with different second-step austempering times after first-step austempering at $280^{\circ} \mathrm{C}$ for $15 \mathrm{~min}$

\begin{tabular}{cccccc}
$\begin{array}{c}\text { Second step } \\
\text { time }\left({ }^{\circ} \mathbf{C}\right)\end{array}$ & $\begin{array}{c}\text { Ultimate tensile } \\
\text { strength }(\mathrm{MPa})\end{array}$ & $\begin{array}{c}\text { Yield strength } \\
(\mathbf{M P a})\end{array}$ & $\begin{array}{c}\text { Elongation } \\
(\%)\end{array}$ & $\begin{array}{c}\text { Impact energy } \\
(\mathrm{J})\end{array}$ & $\begin{array}{c}\text { Fracture toughness } \\
\left(\mathrm{MPa} \cdot \mathbf{m}^{1 / 2}\right)\end{array}$ \\
\hline $30 \mathrm{~min}$ & 1,315 & 1,175 & 7.5 & 132 & 71.91 \\
$45 \mathrm{~min}$ & 1,320 & 1,170 & 8 & 127.8 & 72.78 \\
$60 \mathrm{~min}$ & 1,320 & 1,180 & 8 & 124 & 67.99 \\
$90 \mathrm{~min}$ & 1,350 & 1,290 & 9.2 & 124 & 68.03
\end{tabular}

\section{Conclusions}

(1) The microstructure of the two-step Cu-alloyed ADI is consisted of two different morphologies of ferrites and retained austenites. Acicular ferrite is the product of the firststep austempering, and bunched ferrite is formed during the second-step austempering. Bunched ferrites and acicular ferrites are essentially the same in morphology, but possess different thicknesses and distributions caused by the two-step austempering process.
(2) With the increase of the second-step austempering temperature, bunched ferrites are coarsened, the austenite content and its carbon content are decreased. Carbides begin to precipitate and austenites are decomposed as the second-step austempering temperature reaches $380{ }^{\circ} \mathrm{C}$. When the secondstep austempering temperature reaches $400{ }^{\circ} \mathrm{C}$, the austenites are entirely decomposed. With extending of the second-step austempering time, ferrite morphology remains unchanged, blocky austenites are refined, retained austenite content is 
continuously decreased, and carbon content of retained austenite is increased.

(3) With the increase of second-step austempering temperature, the ultimate tensile strength and yield strength change slightly. Elongation remains constant as the second-step austempering temperature increases from 320 to $360{ }^{\circ} \mathrm{C}$, and then it dramatically decreases due to the carbide precipitation and austenite decomposition. Impact energy and fracture toughness are constantly decreased with the increase of the second-step austempering temperature. This is a comprehensive result of austenite content and its carbon content decreasing, coarsening of bunched ferrite, and carbide precipitation.

(4) With the increase of the second-step austempering time, the ultimate tensile strength, yield strength and elongation are gradually increased, and the impact energy and fracture toughness are gradually decreased due to the austenite refinement and decrease of austenite amount.

(5) In the second-step austempering process, enhancement of carbon diffusion is the main reason for austenite content and its carbon content variation. Nucleation of bunched ferrite influences the size of blocky austenite and carbon diffusion distance. These factors together influence the mechanical properties of two-step Cu-alloyed ADI. The second-step austempering plays an important role in improving austenitic content and mechanical properties, which has a great influence on plasticity and toughness of ADI.

\section{References}

[1] Blackmore R A, Harding R A. The Effects of Metallurgical Process Variables on the Properties of Austempered Ductile Irons. Journal of Heat Treating, 1984, 3: 310-325.

[2] Fuller A G. Austempered Ductile Irons-Present Applications. Materials \& Design 1985, 6: 127-130.

[3] Hughes I C H. Austempered Ductile Irons-their Properties and Significance. Materials \& Design, 1985, 6: 124-126.

[4] Kuna M, Springmann M, Mädler K, et al. Fracture mechanics based design of a railway wheel made of austempered ductile iron. Engineering Fracture Mechanics, 2005, 72: 241-253.

[5] Liu S-f, Yang C, Xin C, et al. Microstructures and Mechanical Properties of Helical Bevel Gears Made by Mn-Cu Alloyed Austempered Ductile Iron. Journal of Iron and Steel Research, International, 2012, 19: 36-42.

[6] Shu D L. Mechanical properties of engineering materials. Beijing: Metallurgical Industry Press, 2007: 66-67. (In Chinese)

[7] Eric O, Sidjanin L, Miskovic Z, et al. Microstructure and toughness of CuNiMo austempered ductile iron. Materials Letters, 2004, 58: 2707-2711.

[8] Zandira M, Boutorabi S M A. Fracture Characteristics of Austempered Spheroidal Graphite Aluminum Cast Irons. Journal of Iron and Steel Research, International, 2010, 17: 31-35.

[9] Zhang J, Zhang N, Zhang M, et al. Microstructure and mechanical properties of austempered ductile iron with different strength grades. Materials Letters, 2014, 119: 47-50.

[10] Vadiraj A, Balachandran G, Kamaraj M. Structure and Property Studies on Austempered and As-Cast Ausferritic Gray Cast Irons. Journal of Materials Engineering and Performance, 2009, 19: 976-983.
[11] Santos H, Duarte A, Seabra J. Austempered ductile iron with tempered martensite. International Journal of Cast Metals Research, 2016, 15: 117-124.

[12] Meena A, Mansori M El. Material Characterization of Austempered Ductile Iron (ADI) Produced by a Sustainable Continuous CastingHeat Treatment Process. Metallurgical and Materials Transactions A, 2012, 43: 4755-4766.

[13] Abdullah B, Alias S K,Jaffar A, et al. Tensile Strength Properties of Niobium Alloyed Austempered Ductile Iron on Different Austempering Time. Advanced Materials Research, 2012, 457-458: 1155-1158.

[14] Haghdadi N, Bazaz B, Erfanian-Naziftoosi H R, et al. Microstructural and mechanical characteristics of Al-alloyed ductile iron upon casting and annealing. International Journal of Minerals, Metallurgy, and Materials, 2012, 19: 812-820.

[15] Kiani-Rashid A R, Edmonds D V. Microstructural characteristics of Al-alloyed austempered ductile irons. Journal of Alloys and Compounds, 2009, 477: 391-398.

[16] Hsu C-H, Chuang T-L. Influence of Stepped Austempering Process on the Fracture Toughness of Austempered Ductile Iron. Metallurgical and Materials Transactions A, 2001, 32A: 2509-2514.

[17] Putatunda S K. Development of austempered ductile cast iron (ADI) with simultaneous high yield strength and fracture toughness by a novel two-step austempering process. Materials Science and Engineering A, 2001, 315: 70-80.

[18] Putatunda S K. Improvement in Stress Corrosion Crack Growth Resistance of an Austempered Cast Steel by a Novel Two-Step Austempering Process. Materials and Manufacturing Processes, 2003, 18: 667-684.

[19] Putatunda S K, Yang J H. A Novel Processing of Austempered Ductile Cast Iron (ADI). Materials Science Forum, 2003, 426-432: 913-918.

[20] Yang J, Putatunda S K. Improvement in strength and toughness of austempered ductile cast iron by a novel two-step austempering process. Materials \& Design, 2004, 25: 219-230.

[21] Martínez-Madrid M, Acosta M A, Torres-Acosta A, et al. Effects of Austempering Temperature on Fatigue Crack Rate Propagation in a Series of Modified (Cu, Ni, and/or Mo) Nodular Irons. Journal of Materials Engineering and Performance, 2002, 11: 651-658.

[22] Rao P P, Putatunda S K. Dependence of Fracture Toughness of Austempered Ductile Iron on Austempering Temperature. Metallurgical and Materials Transactions A, 1998, 29: 3005-3016.

[23] Achary J, Venugopalan d. Microstructural development and austempering Kinetics of Ductile Iron during Thermomechanical Processing. Metallurgical and Materials Transactions A, 2000, 31: 2575-2585.

[24] Rao P P, Putatunda S K. Investigations on the fracture toughness of austempered ductile iron alloyed with chromium. Materials Science and Engineering A, 2003, 346: 254-265.

[25] Bhadeshia H K D H, Christian J W. Bainite in Steels. Metallurgical Transactions A, 1990, 21: 767-797.

[26] Sandvik B P J. The Bainite Reaction in Fe-Si-C Alloys: The Primary Stage. Metallurgical Transactions A, 1982, 13: 777-787.

[27] Panneerselvam S, C J Martis, S K Putatunda, et al. An investigation on the stability of austenite in Austempered Ductile Cast Iron (ADI). Materials Science and Engineering: A, 2015, 626: 237-246.

[28] Trudel A, Gagne M. Effect of composition and heat treatment parameters on the characteristics of austempered ductile irons. Canadian Metallurgical Quarterly, 1997, 36: 289-298.

[29] Olofsson J, Larsson D, Svensson I L. Effect of Austempering on Plastic Behavior of Some Austempered Ductile Iron Alloys. Metallurgical and Materials Transactions A, 2011, 42: 3999-4007.

[30] Gutierrez I, Aranzabal J, Castro F, et al. Homogeneous Formation of Epsilon Carbides within the Austenite during the Isothermal Transformation of a Ductile Iron at $410^{\circ} \mathrm{C}$. Metallurgical and Materials Transactions A, 1995, 26: 1045-1060. 